\title{
Lower Jaw Tooth
}

National Cancer Institute

\section{Source}

National Cancer Institute. Lower Jaw Tooth. NCI Thesaurus. Code C49582.

Any of the teeth located in the mandible. 